\title{
Change or Continuity in US-Latin American Policy: the Obama Record
}

Stephen J. Randall

Latin American Research Centre University of Calgary

srandall@ucalgary.ca

There has been little praise and considerable criticism of the Latin American policies of the first presidential term and the early stages of the second administration of Barack Obama. It is understandable that his administration has had major distractions domestically and internationally with the fallout from the financial crisis, political wrangling over health care reform, crises in Egypt and Syria, sable rattling from North Korea, the need to continue to build a stable relationship with China, and winding down wars in Afghanistan and Iraq. Since the mid-term Congressional elections in 2010, the President has also faced congressional deadlock over virtually every administration initiative, from the confirmation of nominees to executive positions to immigration reform. Given those challenges and what had to be priorities, it was inevitable that Latin American policies would suffer to some degree. Condolences and understanding aside, the gap between President Obamas lofty rhetoric and actual policy accomplishments is significant and growing. Latin American Perspectives (2011), for instance, recently characterized his administration's policies as "dangerous complacencies." Other commentators have suggested there is more continuity than change from the George Bush policies which he so vigorously criticized in 2008 (2011, pp. 14-28). This paper reviews the regional policies, successes and failures, of the administration over the past 5 years with particular focus on Honduras, Colombia and Mexico, three of the regional countries which have posed the most significant challenges.

On Cuban policy during the campaign, Obama was explicit in calling for change at least in terms of lifting travel restrictions and controls on remittances for Cuban Americans with family on the island. Speaking before the Cuban American Foundation in Miami in May 2008 he pledged to immediately allow unlimited family travel and remittances. $\mathrm{He}$ also indicated that he was prepared, with proper preparation, to meet with Raul Castro. He made no reference to the embargo. On broader Latin American policy he was critical of the U.S.-Colombian trade agreement, which both he and Hillary Clinton criticized in the Democratic Party primary campaign (Strassel, 2008). 
Once he had secured the nomination and moved into the presidential campaign against Republican John McCain, Obama made few references to Latin American issues; they simply did not resonate with the electorate in the fall of 2008. The ввC's Latin American analyst James Painter predicted that there would be a change in tone but little substantive change in actual policy with an Obama administration ${ }^{1}$.

The first administration began with a mixture of the same optimistic and positive rhetorical flourishes which had characterized the 2008 presidential election campaign. There had been a great deal of popular support for the Obama candidacy in Latin America, partly because he was African-American and partly because of his democratic, liberating and inspirational message of change. Brazilian President Inácio Lula da Silva stressed the significance of Obama's race (Erikson, 2010, p. 7). Only a few months after taking office, in April 2009, speaking before the Fifth Summit of the Americas in Trinidad, Obama spoke of a new era in U.S.-Latin American relations and pledged to respect sovereignty and diversity in the region. His commitment was unequivocal: "I know that promises of partnership have gone unfulfilled in the past, and that trust has to be earned over time. While the United States has done much to promote peace and prosperity in the hemisphere, we have at times been disengaged, and at times we sought to dictate our terms. But I pledge to you that we seek an equal partnership. There is no senior partner and junior partner in our relations; there is simply engagement based on mutual respect and common interests and shared values. So I'm here to launch a new chapter of engagement that will be sustained throughout my administration." President Obama identified a number of specific areas in which he sought improvement: stimulating economic growth; supporting an expansion of Inter-American Development Bank lending capacity; combating inequality and creating prosperity from the bottom up; addressing violence and insecurity; reducing U.S. demand for illicit drugs; stopping the illegal flow of arms by giving priority to ratification of the un Protocol on Illicit Traffic in Firearms and the Inter-American Convention Against the Illicit Manufacturing and Trafficking in Firearms; establishing an Energy and Climate Partnership for the Americas; and "a new beginning with Cuba"2.

The record since 2009 has been disappointing when measured against the promises. Once in office there was a minor initiative to ease travel restrictions to Cuba, but by the time of the $6^{\text {th }}$ Summit of the Americas in Cartagena in 2012, President Obama indicated that there would be no change in U.S.-Cuban policy in spite of the almost unanimous support for a reintegration of Cuba into the Inter-American system by countries in the hemisphere, Canada being the other opposition. The isolated nature of the U.S. position on Cuba is reflected

http://news.bbc.co.uk/2/hi/americas/us_elections_2008/7710855.stm.

2 Fifth Summit of the Americas. Recuperado de http://www.trinidadandtobagonews.com/5summit/obama170409. html. 
in the UN vote as well. The year that Obama took office the General Assembly voted 187 2 condemning the embargo policy, with only Israel joining the United States in the vote. Secretary of State Hillary Rodham Clinton made the curious statement in 2010 that it was her personal opinion that the Castros did not want a normalization of relations because it would expose their policies for the failures that they have been ${ }^{3}$. Certainly there was no hint from her of a shift in U.S.-Cuba policy.

Nor was there any sign of significant change on Cuban policy in the first several months of the second term. Former Senator John Kerry, Clinton's successor as Secretary of State, has signaled no change. Cuba was still on the list of state sponsors of terrorism. In February 2013 the New York based Council on the Americas and the Washington based Cuba Study Group both called on the administration to lift the embargo. The administration did not respond. In May 2013, as a possible sign of a U.S. overture to reduce tensions with Cuba, a US court allowed René Gonzalez to return to Cuba. Gonzalez was one of the Cuban Five who had been in a U.S. prison until 2011 serving time for engaging in espionage (Hayden, 2013). Any significant shift in policy toward Cuba is unlikely in the balance of Obama's presidency. There is little appetite for such change in Congress or in the Cuban-American community with the exception of the liberalization of travel and remittance restrictions. Any Congressional shift is also unlikely given the fact that Secretary of State John Kerry's successor as chair of the Senate Foreign Relations Committee is Robert Menendez of New Jersey, who has consistently opposed any normalization of relations.

Where Kerry has been able to shift policy directions is on relations with Venezuela, with which the United States has had a troubled relationship for a decade, largely because of the intense anti-American policies pursued by the late president Hugo Chavez. In early June 2013 Kerry met with Venezuelan Foreign Minister Elias Jose Jaua, the first cabinet level meeting between the two countries in several years, and Kerry's first Latin American trip since taking office. There was some expression of hope that there would be a normalization of relations and an exchange of ambassadors in the near future ${ }^{4}$.

With respect to other promises the President made in Trinidad, as of 2013 the United States had not ratified the UN Protocol on Illicit Traffic in Arms nor the Inter-American Convention, in spite of the heightened attention to gun control following the devastating shooting of school children in Newtown, Connecticut in late 2012. The energy initiative had produced some results. By 2012, the U.S. had invested approximately $\$ 150$ million in support for a variety of projects in the region, from electrification projects to training programs, the Caribbean Renewable Energy Strategy, and a number of national energy research centers. On narcotics, security and

Reported by Reuters (April 9, 2010).

Mallett, R. Venezuela-U.S. Relations may improve. Venezuelanalysis.com. 
trade policies, however, critics argue that the administration has simply maintained and extended the initiatives of the Clinton and Bush administrations, from Plan Colombia to the Iniciativa Mérida in Mexico and the conclusion of Bush administration negotiated free trade agreements with Colombia and Panama in spite of opposition from his own party over perceived human rights issues. Nor, although it was not solely a Latin American issue, did Obama follow through on his very vocal commitment to close the Guantánamo detention center.

The relative neglect of Latin America, with a few important exceptions, is indicative of a much broader and more fundamental shift in the relationship between the United States and the region. The United States simply does not have the power or relevance it once had. The decline of U.S. influence in the region is reflected not only in the success which the now late Venezuelan President Hugo Chávez had in extending his Bolivarian vision and oil fueled influence into the Caribbean, Central America and the Andean region, but perhaps more importantly in the emergence of Latin American-led regional organizations in which neither the United States nor Canada is represented (Congressional Research Service, 2012). Such organizations go beyond such regional trading blocs as MERCOSUR. The first of the more recent organizations is UNASUR, the Union of South American Nations, which was established in 2008 at a summit in Brazil. It is essentially an integration of the Mercosur countries with those of the Andean Pact and is modeled on the European Union. It includes 12 countries and a Latin American parliament in Bolivia. A second is CELAC, the Community of Latin American and Caribbean States, established in Caracas in 2011. Its objective is to advance regional integration, and the organization includes 33 countries. Such initiatives are indicative of the growing sense of economic, political and diplomatic power in Latin America, most striking in the case of Brazil, whose inclusion among the BRIC (Brazil, Russia, India, China) countries is an indication of its capacity to play a more important role on the world stage. The efforts of Central and South American countries in the past decade to strengthen their economic relationships in particular with China, Europe and even Iran have reflected this broader tendency to distance themselves from the United States and to build more complex economies and political linkages. As two analysts suggested, "a more self-confident and autonomous majority in Latin America has sometimes sought a policy shift with regard to highly sensitive topics, such as drugs, immigration and Cuba." (Whitehead $\&$ Nolte, 2012). Those initiatives were not limited to Chavez's Venezuela, but included such U.S. allies as Colombia and Mexico.

On one level, this effort on the part of Latin American countries to distance themselves from the United States is ironic since the economic importance of the United States to the region remains strong even if it has declined since 2000. In 2000, some $61 \%$ of Latin American exports went to the United States. By 2010, that had declined to $41 \%$. The change in U.S. exports to the region has shown a similar decline in that period from $55 \%$ to $30.5 \%$. Nonetheless, the United States is still the source for $20 \%$ of foreign direct inves- 
tment in the region and an estimated $90 \%$ of remittances (Whitehead \& Nolte, 2012, p. 3).

A brief examination of Obama administration policies toward three countries serves to illustrate a number of the basic features of the administration's approach to the region, Honduras because of the 2009 constitutional crisis, Mexico because of the extent to which it poses challenges which are in part domestic and in part foreign policies, and Colombia, which because of Plan Colombia has had a special importance to the United States since the Clinton administration.

\section{HONDURAS}

The first major crisis and challenge in Latin America which the Obama administration faced came in Honduras. This was an important litmus test for the relatively new administration. What position it would assume when confronted by a military-backed coup would have important impact on the public perception of the extent to which the new administration was in fact departing from past failed policies. In June 2009 the Honduran Congress and military removed from office leftist President Manuel Zelaya, contending that he was violating the constitution in his efforts to lift restrictions on presidential terms. Honduran congressman Roberto Micheletti was named interim president. The Obama administration had been working for some weeks prior to the coup in an effort to resolve differences between Zelaya and his opponents. There was admittedly a great deal of confusion at the time over the constitutionality of the process by which he was removed, the role of the Supreme
Court, the Congress and the military, and that confusion was reflected in the response of the OAS and some member states. Nonetheless, the Obama administration, along with the OAS, the Bolivarian countries and UNASUR, condemned the removal as a violation of the Democratic Charter. In late June President Obama stated: "We do not want to go back to a dark past," and added, "we always want to stand with democracy" (Malkin, 2009). The administration suspended $\$ 30$ million in aid to Honduras, although this was only a small percentage of the total level of U.S. assistance to the country. The administration did not, however, break diplomatic relations and recall its Ambassador. Critics contended that administration officials were aware of the pending coup and condoned it. They also argued that the administration fell back into the anachronistic bipolar Cold War mentality of seeing the "left" in Latin America as a security threat to U.S. interests, a threat embodied in the anti-Americanism of Hugo Chavez (Latin American Perspectives, 2011, 14-28; Haugaard, 2009). On July 5 the OAs, acting on the basis of Article 21 of the Inter-American Democratic Charter, suspended Honduras.

Months of political and diplomatic wrangling ensued, along with mass public demonstrations in Honduras in support of Zelaya, during which time ousted President Zelaya was given diplomatic asylum in the Brazilian embassy. During that interlude the administration worked with Oscar Arias of Costa Rica in a failed effort to mediate a resolution which would have seen Zelaya returned to office. That and other efforts failed in the face of stiff resistance from the Honduran Congress and 
opposition from U.S. Congressional Conservatives to any solution which would restore Zelaya to power. Conservative Republicans in the Senate used the opportunity of the Honduran coup and the Brazilian opposition to block the confirmation of both the Obama nominee as ambassador to Brazil and the nominee as Assistant Secretary of State for Western Hemisphere Affairs, actions which the German Institute of Global and Area Studies labeled the "hijacking of Latin American policy" (Whitehead \& Nolte, 2012). Honduran authorities pressed on with their intention to hold new elections at the end of 2009. U.S. officials continued to work unsuccessfully to have Honduran officials accept a power sharing government. All efforts failed and the Obama administration took the easier and more pragmatic approach to a solution. In November, senior state department official Thomas Shannon indicated that the United States would recognize the results of the November 29 elections even if Zelaya was not returned to power. The Obama administration ultimately accepted the legitimacy of the elections and recognized the new government of Porfirio Lobo, in contrast to the response of most Latin American countries. Brazilian presidential adviser Marco Aurélio García commented at the end of November: "We have a strong sense of disappointment" in the U.S. position (Thompson, 2009).

Although on the surface the crisis ended with the election and the inauguration of President Porfirio Lobo, the legacy of the coup and the perceived violations of human rights during the demonstrations which had followed the coup persisted. The interim government had suspended freedom of assembly and speech in the period leading up to the November election (Joyce, 2010). In July 2011 the Honduran Truth Commission concluded that Zelaya had broken the law when he disregarded the ruling of the Supreme Court instructing him to cancel the June 2009 referendum. At the same time, the Commission determined that his removal from office was also unconstitutional and that the action should be considered a coup. Finally, it ruled that the appointment of Micheletti as interim president was also unconstitutional.

The U.S. response to the impeachment of President Fernando Lugo in Paraguay in 2012 was even milder. The Obama administration did not assess the Congressional impeachment, for failing to maintain social harmony, led by the conservative Colorado Party, as a coup, although there was some criticism for the haste with which the process was implemented. By contrast, Latin American condemnation of the removal of the reformist president who had pledged to address poverty and engage in land reform, was immediate. Brazil, Argentina, Uruguay and Chile withdrew their ambassadors. UNASUR and Mercosur immediately suspended Paraguay. The oAs did not sanction Paraguay and the Obama administration followed the OAs lead. In April 2013 the OAS sent official observers to monitor new elections which brought right wing Colorado Party candidate Horacio Cartes to power, ending what little opportunity there had been for substantive reforms which might have challenged large landowners and agribusiness. 


\section{MEXICO}

If one considers that narcotics, arms and human trafficking, and immigration are among the three most important policy issues facing the United States in Latin America then Mexico is the country with which the Obama administration has most needed to "get policy right." Few analysts would give the administration passing grades in its Mexico policy. Immigration reform as of 2013 is still mired in the stew that has characterized Congressional politics. There is no consensus on how to deal with the estimated eleven million illegal immigrants in the United States. Conservatives want even more security on the border with Mexico but are opposed to any of the arms control measures which might actually improve border security. Narcotics policies, in spite of rhetoric that recognizes that the war on drugs has been a failure, is still based on a mano dura approach. Obama has stated that he understands that American consumption of illegal narcotics is a major contributing factor. He has also made clear that he understands that guns flow from the United States into Mexico to meet the demand of criminal organizations, but those guns continue to flow five years after his election. It is understood that the President cannot control Congress and that the NRA continues to wield power over many elected representatives who might otherwise support gun control. Indicative of that level of influence is the fact that the Bureau of Tobacco, Alcohol and Firearms, under NRA and Congressional pressures, stopped releasing data on the percentage of weapons seized in
Mexico that had been purchased in the United States (Vanderbush, 2011).

President Obama's election coincided with the militarization of the conflict with the narcotics cartels during President Felipe Calderón's administration. He also inherited the Merida Initiative which allocated substantial U.S. support to Mexican (as well as Central American) military and law enforcement as well as judicial officials to control narcotics production, trafficking and organized crime. In 2008, Congress appropriated $\$ 400$ million for Mexico and an additional $\$ 65$ million for Central America. In his first year in office President Obama signed another $\$ 300$ million into law for the program. By 2012, the U.S. congress had appropriated $\$ 1.6$ billion under the program (U.S. Department of State, 2012). In 2009, President Calderón sent 5,000 federal troops into Ciudad Juarez on the U.S. border. The city, and northern Chihuahua in general, had been the site of sustained conflict among competing drug cartels. The initiative yielded some limited success against the cartels but in the process thousands of civilians have also lost their lives. Scholars have shown statistically, for instance, that the militarization of the war against the cartels in Ciudad Juarez resulted in a significant increase in homicides against women (Méndez, 2013).

The election of PRI candidate Enrique Peña Nieto in 2012 promised to bring a shift in Mexican policies, a scaling down of military operations against the cartels, more federal collaboration with state and municipal authorities, more focus on the protection of human rights, and some attention to the 
social and economic factors which give rise to criminal activity. He has also worked to develop a more effective working relationship with the other leading political parties in Mexico in order to achieve reforms in such critical areas as energy, where there have been signs that the oil industry will be more open to foreign investment, as well as in education and communications. As Peter Hakim of the Inter-American Dialogue noted in early May 2013 as President Obama met with his newly inaugurated Mexican counterpart, Mexico's image in the United States was not positive. It was viewed as corrupt, with a weak human rights record, the source of most of the illegal immigration entering the United States, or already there, as well as the cause of border state violence and narcotics trafficking into the country. Yet, as Hakim also observed, it is economically significant to the United States, with some forecasts predicting that it will replace Canada as the largest trading partner of the United States in less than a decade. From a Mexican perspective, immigration reform in the United States is one of the most important objectives which the Obama administration could achieve, since it has long been a source of anger among Mexicans. Whether substantial reform will be attained remains to be seen.

U.S.-Mexico relations are so closely tied to the broader debate over immigration policy and drug trafficking that it is difficult to say what is specific to Mexico and what constitutes U.S. domestic policy. Democrats in Congress have had little choice except to concede to harsher border controls toward Mexico in order to obtain Republican support for immigration reform, and even then, hard line conservatives remain opposed in principle to immigration reform if it amounts to an amnesty for undocumented immigrants, recalling that the last time there was an amnesty the result was an increase in illegal migration across the border with Mexico. Irreconcilables include, among others, Republican Senators Jeff Sessions, Alabama, and two Texas Senators, Ted Cruz and John Cornyn (Shear, 2013, p. A1). The irony is that border security is tighter now than at any previous time. Since 2005, the number of border patrol agents in the U.S. southwest has nearly doubled. The air wing of Customs and Border Protection is well equipped with air surveillance capacity. Technological surveillance has become highly sophisticated and effective, and the entire operation has taken on a military command structure.

The Obama administration is caught between two very different visions of how to deal with Mexico. The President in his overall approach to narcotics trafficking and in specific reference to Mexico has argued from his first year in office that there needs to be more emphasis on economic development and less emphasis on the military approach to dealing with drugs. Obama has also sought to distance his administration to a considerable degree from the internal policies and especially the high levels of violence within Mexico. He stressed in his May 2013 meetings with President Peña Nieto that Mexico needs to set its own course on its security challenges, with the United States playing a purely supportive role. That approach coincides with Peña Nieto's desire to reduce U.S. involvement in law enforcement on the Mexican side of the border, in part to reduce the tensions and distrust 
that exist between Mexican and U.S. officials (Preston, 2013, p. A1; Shear, 2013, p. A10). The problems of organized crime, narcotics and arms trafficking, human rights violations and illegal migration are certain to remain persistent issues in the U.S.-Mexican bilateral relations for the foreseeable future.

\section{COLOMBIA}

The Obama administration overlapped with the last two years of the Presidency of Alvaro Uribe Vélez before the election of former Minister of Defense Juan Manuel Santos in 2010. The Obama administration inherited the ongoing Plan Colombia, which since 1999, when it was initiated by Presidents Clinton and Pastrana, had allocated approximately $\$ 6$ billion, most of which was dedicated to assisting Colombia with military and national police training as well as with military and communication technology. Initially, aid was strictly to be allocated to the effort to eradicate coca crops and counteract narcotics trafficking, but after 9/11 and the designation of FARC and the ELN as terrorist organizations the assistance took on a counter-insurgency dimension as well. The administration also inherited a free trade agreement that had been negotiated and signed during the George W. Bush presidency but not ratified, in large part because of opposition in Congress from Democrats critical of Colombia's human rights record.

Controversial as his administration was, Uribe's presidency had witnessed a dramatic shift in the strength of the state in its decades' long conflict with FARC. During the three years that Santos served as Minister of Defense, the state had established a police and/or military and civilian presence in all of the country's municipalities, many of which in the 1980s and 1990s had been largely abandoned to FARC, the ELN or in some cases to paramilitaries. As well, the Colombian strategy of targeting FARC leaders had born fruit, with two of the major figures killed in military action and the third, Mario Marulanda or Tiro Fijo, the founder and leader of FARC, dying of natural causes. Santos had also presided over the Colombian-U.S. joint operation "Operación Jaque", which liberated former presidential candidate Ingrid Betancourt and another fourteen high profile farc hostages. This success had not been without controversy, however, with Colombian and international NGos identifying significant levels of human rights violations and continued displacement of small town and rural Colombians uprooted by the escalated violence of contending forces (UNHCHR, 2006). Criticism of Colombian human rights violations was reinforced by President Uribe's decision to relieve of duty three of his top generals along with four colonels following the military killing of eleven men in the town of Soacha, individuals who were falsely reported by the military as insurgents. This was only a month prior to Obama's election in November 2008. An indication of how pervasive the problem was is reflected in the fact that by 2010, approximately four hundred soldiers and officers were being investigated by the military for alleged involvement in extrajudicial killings, and the Prosecutor General's Office was investigating several hundred others.

In addition to improvements in containing FARC, extending the power of the state, 
and attempting to address human rights violations, the Uribe government by the time Obama took office in 2009 had also begun a large scale demobilization of paramilitary organizations. Between 2003 and 2006, approximately 32,000 members of the AUC, United Self-Defense Forces of Colombia, originally established in 1997 by Carlos Castaño, had agreed to disband and surrender their weapons. In spite of the fact that many former paramilitaries simply blended in to other criminal organizations, the demobilization process and the beginnings of an effort to address the victims of decades of violence and displacement were at least movement in the right direction.

Economic conditions also improved during the Uribe presidency, with a decline in the unemployment rate, increases in foreign direct investment and in the annual growth rate, at least until the economic slowdown in 2008 in the context of the global recession. In 2009, as the recession deepened and the war on drugs in Mexico called for increased resources, the Obama administration spoke about the need to reduce its financial commitment to Plan Colombia in fiscal year 2010 and to place more of the financial responsibility on Colombian authorities. At the same time the Obama administration perceived advances in human rights and in the credibility of the Colombian government to make the free trade agreement politically more palatable. With the transition to Santos from Uribe the U.S. Trade Representative, Ron Kirk, indicated the administration would be dusting off the trade agreement and renewing efforts at ratifica- tion. Renewing the effort to ratify the trade agreement was controversial but it had strong support from Congressional conservatives and from leading conservative think tanks such as the Heritage Foundation, which suggested in the context of Santos's inauguration that the Obama administration was "inching toward a mid-course correction in its policy" toward Colombia (Walser, 2010).

On the military side, in 2009, Uribe negotiated an agreement with the Obama administration providing the United States access to seven military bases. The U.S. military was anxious to conclude this agreement since the government of Rafael Vicente Correa in Ecuador in 2008 announced it would not be renewing the ten year agreement providing U.S. Air Force access to the major base at Manta. At the time of the decision there were 450 U.S. Air Force personnel and contractors at Manta. The Washington Post captured the prevailing political mood in pro-Chávez Ecuador at the time in quoting Gustavo Larrea, Ecuador's security minister: "The U.S. stopped being the benchmark of what is good for Latin America," he said. "Because Latin America did everything that the U.S. asked it to do and wasn't able to get out of poverty, the North American myth lost political weight" (Partlow, 2008). The most significant and controversial of the seven Colombian bases was the Palanquero base northwest of Bogotá, adjacent to the Magdalena River. The agreement provided for the U.S. to invest $\$ 46$ million in upgraded facilities at the base, which already had the capacity to accommodate100 planes, including C-17 troop carriers. At the same time, the agreement 
did not increase the number of U.S. military personnel in the country, which continued to be limited to 1,400 by U.S. law.

The intent of the base, according to U.S. Air Force documents, was "to leverage existing infrastructure to the maximum extent possible, improve the U.S. ability to respond rapidly to crisis, and assure regional access and presence at minimum cost. [...] Palanquero will provide joint use capability to the U.S. Army, Air Force, Marines, and U.S. Interagency aircraft and personnel"s.

The regional reaction to the agreement was almost uniformly negative. Venezuelan President Chávez was predictably the most outspoken, claiming that Colombia had compromised its own sovereignty and that of its neighbors. Chavez sabre rattled and ordered troops to the Colombian border. Wisely, President Uribe ignored the action. Ecuador and Brazil, however, were equally concerned, with Brazil suggesting that the agreement, on which Brazil was not consulted, threatened to destabilize the relationship with Colombia's neighbors. President Michelle Bachelet of Chile also expressed concern. UNASUR met to discuss the agreement and President Lula of Brazil suggested that President Obama should be invited to explain the U.S. position. Colombian Deputy Foreign Minister, Clemencia Forero, who represented Colombia at the 2009 UNASUR meeting in Quito, said the agreement only provided limited access for U.S. personnel and was focused on drug trafficking. "There haven't been any foreign military bases in Colombia and there won't be any," she was quoted as saying. "The bases remain under Colombian jurisdiction and sovereignty" ${ }^{3}$. Critics were not limited to the neighboring countries. A number of Colombian legislators also denounced the agreement. As well, a lawyers' group filed suit on the grounds that without legislative approval the agreement was unconstitutional, and in a ruling the following year the Colombian Constitutional Court agreed (Brodzinsky, 2010).

President Obama sought to allay fears of a U.S. military buildup in the region. He told Reuters that "We have had a security agreement with Colombia for many years now. We have updated that agreement. We have no intent in establishing a U.S. military base in Colombia." He added that the agreement was a continuation of current U.S. assistance to Colombia. "We have no intention of sending large numbers of additional troops into Colombia, and we have every interest in seeing Colombia and its neighbors operate peacefully"7. In April 2012 President Obama met with President Santos and signed a new U.S.-Colombia Action Plan on Regional Security. The White House said in a statement that discussions between technical experts and policy officials would focus on four key areas that align with hemispheric citizen security goals and priorities. Those included fighting

\footnotetext{
5 Reported in The Progressive (March 2010).

6 http://colombiareports.com/lula-suggests-meeting-with-obama-about-us-military-in-colombia/.

7 Reuters (August 7, 2009).
} 
narcotics trafficking, combating crime, strengthening institutions, and fostering resilient communities. Both countries, the White House said, would develop complementary security assistance programs and operational efforts to support hemispheric and international partner nations afflicted by effects of transnational organized crime ${ }^{8}$.

That same month, Defense Secretary Leon Panetta assured his counterparts at the 2012 Conference of Defense Ministers of the Americas that the United States had no intention of establishing permanent military bases in the Americas. In April that year he met in Bogotá with his Colombian counterpart Juan Carlos Pinzón Bueno. At meetings in the capital and at Tolemaida, the large airbase near the city, Panetta reaffirmed the U.S. commitment to assist Colombia in the defeat of Farc. He also noted that recent Colombian success in addressing its security situation was enabling it to cooperate in assisting other countries, notably in Central America?.

Until Santos succeeded Uribe as President in 2010 opposition in the United States to the free trade agreement was insurmountable. The Colombian Senate ratified the agreement in October 2007 by a vote of 54-16 and the Colombian Constitutional Court approved the agreement the following year. There were concerns in both the United States and Colombia about the agreement, especially among human rights groups and organized labor. In Colombia the CGT, the General Confederation of Labor, opposed the agreement. Prior to ratification, the ELN (National Liberation Army) indicated that it would agree on a unilateral ceasefire only if the government did not ratify the free trade agreement (Rodríguez, 2007). The Polo Democrático Party opposed the agreement. Even before Obama had obtained the Democratic Party nomination for President, Polo Democrático wrote to Congresswoman Nancy Pelosi, and Senators Harry Reid, Hillary Clinton and Barack Obama in April 2008 urging the Democrats to vote against the agreement, arguing that the "FTA benefits only a select minority in the United States, not the general population. For example, the destruction of Colombian agriculture caused by the FTA will stimulate the planting of coca in Colombia and more drug dealing in the streets of American cities" ${ }^{\prime 10}$. Colombian Liberal Senator Cecilia López objected to the fast tracking of debate in the Colombian Congress by the Uribistas (Semana, 2007). In the United States, organized labor was outspoken in opposition, notably the United Steelworkers, which opposed at the outset and continued to do so even after it was finally ratified in 2011 because of the targeting of labor activists by paramilitary organizations. Democrats in Congress indicated that they would not support an agreement unless there were clear guarantees that the

\footnotetext{
8 http://www.defense.gov/news/newsarticle.aspx?id=116054.

9 http://www.defense.gov/news/newsarticle.aspx?id=116054.

10 Letter of April 4, 2008. Recuperado de http://colombiasupport.net/2008/04/letter-from-the-polo-democraticoparty-to-nancy-pelosi-on-the-fta/.
} 
Colombian government was not supporting paramilitary groups, a position that reflected the accusations in Colombia of links between Uribe's government and the paramilitaries ${ }^{11}$. Senator Hillary Clinton was outspoken in her opposition to the agreement during her bid for the Democratic Party presidential nomination. The New York Times editorialized in October 2007 that of the trade agreements before Congress should be delayed. "Uribe and his government," the Times contended, "have not done enough to bring to justice the paramilitary thugs and their political backers" (2007, p. A18). Republican Senator Richard Lugar responded with an op-ed in the Miami Herald in which he argued that the U.S. would be assisting Colombia to solve some of its challenges by ratifying the trade agreement. The Washington Post concurred, editorializing on November 9 that it was time for the Democrats to assess the agreement on its merits and that as much as the country's progress was fragile and incomplete, there had been improvement in the application of justice to those responsible for the violence (Semana, 2007; Iragorri, 2007).

Given the broad range of opposition to the agreement from his own party, Obama made no move to encourage ratification until after Santos was in power in Colombia and the Republican Party had gained control of the House of Representatives in the 2010 mid- term elections. In order to move the agreement forward in Congress Obama and Santos agreed on a range of provisions which Colombia was expected to implement to protect labor rights (The Economist, 2011). Under the Colombian Action Plan Related to Labor Rights, Colombia passed legislation criminalizing interference in the execution of labor rights, advanced fines for maintaining employment relationships that undermine workers' rights, expanded protection for union members, and reformed the procedures in the Office of the Prosecutor General to improve the prosecution of cases involving the killing of union members ${ }^{12}$.

The Obama administration stressed the mutual advantages of the agreement. For Colombia, it predicted that within five years the enhanced trade would increase the Colombian growth rate by half a percentage point. The Office of the US Trade Representative noted that in 2010 Colombia was already the second highest importer of U.S. agricultural exports in Latin America. The agreement also opened up the Colombian service sector market to American providers ${ }^{13}$. The Economist reported that it was expected that Colombian exports to the United States under the agreement would increase from $\$ 17$ billion to $\$ 50$ billion a year (The Economist, 2011).

When the trade agreement finally came to a vote in October 2011, Democratic opposition was still strong, and Obama, like Clinton

\footnotetext{
11 Democrats in Congress were also successful in reducing U.S. military aid to Colombia and diverting a higher percentage of that aid to economic development and strengthening the judicial system. Democratic members of Congress also expressed concern about the marginalization of Afro-Colombian communities (Ikeda, 2007).

12 www.ustr.gov/uscolombiatpa.

13 Ibid.
} 
in 1994 with the North American Free Trade Agreement, had to count on Republican votes. The House voted 262-167 and the Senate 66-33 in favor. In the Senate, Democrats were divided. Democratic Senator Max Baucus, Chair of the Finance Committee, was a leading supporter of the agreement, but Ohio Democratic Senator Sherrod Brown an outspoken opponent. Senate majority leader Harry Reid voted against the treaty. In the House, Maine Democrat Mike Michaud indicated his negative vote was based on concern over potential job losses to other countries; Democrat Lloyd Doggett of Texas suggested his concerns focused on the continuing problems of human rights violations, and Michigan Democrat Sander Levin opposed on grounds related to the rights of labor (Applebaum, 2011, p. A1).

When the agreement was ratified in 2011, the website of the Office of the U.S. Trade Representative featured statements of various interest groups supporting the trade pact. None of the statements came from an NGO or trade union $^{14}$. Leon Valencia, writing in Semana in April 2011, argued that the final terms of the agreement represented a victory for Colombian labor because it had been successful in obliging Colombia to protect and extend the rights of labor in the face of those who sought to repress those rights. Valencia (2011) noted that between 1986 and 2010 there had been more than 2700 trade unionists murdered in Colombia. Trade union concerns persisted, however. In April 2012 shortly before President Obama left for the Summit of the Americas in Cartagena the President of the AfL-CiO, Richard Tremka, wrote to Obama urging him to continue to press Colombian authorities on the killing of labor activists (Calmes, 2012, p. A12). In Colombia there was opposition from labor groups, and from smaller-scale farmers in rice and corn production as well as dairy farmers and poultry producers. The Uribe government had set up a system of subsidies for small farmers, but the program became mired in scandal when funds intended for the smaller producers were diverted to large landowners. Nor did the Colombian government take advantage of the five years between negotiation and ratification of the agreement to engage in the infrastructure renewal that was deemed necessary for an effective implementation of the agreement, including upgrading port facilities and improving highways (The Economist, 2011).

\section{CONCLUSION}

The record of the Obama administration toward Latin America since early 2009 has been, as suggested here, a very mixed one in which rhetoric and good intentions have been challenged time and again by the realities of domestic and international relations and power politics. Obama has maneuvered around these shoals with some political skill, retreating when necessary to a position of political pragmatism. The administration has been beset by problems larger than Latin American relations: winding down large scale military commitments in Iraq and Afghanistan; the

\footnotetext{
14 www.ustr.gov/uscolombiatpa.
} 
waning of the euphoria that accompanied the initial stages of the "Arab Spring;" the continuing need to address the financial crisis and its fallout; responding to challenges posed by Iranian and North Korean nuclear programs. Perhaps most importantly the United States has had to come to terms with the fact that it has limited capacity to dictate the course of events in Latin America.

\section{REFERENCES}

Applebaum, B. (October 13, 2011). Trade Deals Pass Congress. New York Times.

Brodzinsky, S. (August 7, 2010). Behind Uribe's New Colombia. The Guardian.

Calmes, J. (April 13, 2012). Trade, Energy and Drugs are Topics for Obama. New York Times.

Congressional Research Service (2012). Latin America and the Caribbean: U.S. Policy and Key Issues for Congress in 2012. Washington D.C.

Erikson, D. (April 2010). The Obama Administration and Latin America: Towards a New Partnership? Centre for International Governance Innovation. Working Paper (46).

Fifth Summit of the Americas. Recuperado de http:// www.trinidadandtobagonews.com/5summit/ obama170409.html.

Haugaard, L. (2009). Latin American Working Group. Hayden, T. (May 21, 2013). Americas Program. Recuperado de http://www.cipamericas.org/archives/9505.

Ikeda, N. (June 7, 2007). Con constancia el presidente Uribe trata de superar las trabas en el congreso de EE.UU. Semana.

Iragorri, J. C. (November 9, 2007). Una muy seria publicación de EE.UU. asegura que relación de Uribe con los paras es sospecha. Semana.
Joyce, R. (March-April 2010). Legitimizing the Illegitimate. NACLA Report on the Amerias.

Julia Preston (March 16, 2013). Arizona Borders. New York Times.

Latin American Perspectives (July 2011), 38 (4), 14-28.

Malkin, E. (June 29, 2009). Honduran President is Ousted in Coup. New York Times.

Mallett, R. Venezuela-U.S. Relations may improve. Venezuelanalysis.com.

Mendez, Z. (May 2, 2013). Paper presented at a conference on Latin American Security. Latin American Research Centre, University of Calgary.

New York Times (October 8, 2007). Editorial: Democrats Talk Sense to Democrats.

Partlow, J. (September 4, 2008). Ecuador Giving U.S. Air Base the Boot. Washington Post.

Rodríguez, A. (May 23, 2007). El ELN ofrece cese del fuego. Semana.

Semana (May 12, 2007). Duro de roer; TLC duro de concretar.

Semana (October 13, 2007). Agite por el TLC.

Shear, M. (June 10, 2013). Senate Digs in for long battle over immigration reform. New York Times.

Shear, M. (May 5, 2013). Latin America U.S. Focus Shifts from Drug War to Economy. New York Times.

Strassel, K. (May 23, 2008). The Obama Learning Curve. The Wall Street Journal.

Recuperado de http://news.bbc.co.uk/2/hi/americas/us_elections_2008/7710855.stm.

The Economist (October 15, 2011). Get Cracking: the Colombia-United States Free Trade Agreement.

Thompson, G. (November 28, 2009). Region finds US Lacking on Honduras. New York Times.

U.S. Department of State (March 29, 2012). The Merida Initiative: Expanding the U.S./Mexico Partnership. www.state.gov/p/wha/rls/fs/2012/187119. htm. 
uN High Commission for Human Rights (2006). Informe Anual del unHCHr para los Derechos Humanos en Colombia.

Valencia, L. (April 9, 2011). La hora del sindicalismo. Semana.

Vanderbush, W. (Summer 2011). Good Neighbor Imperialism: U.S.-Latin American Relations Under Obama. New Politics, XIII (3).
Walser, R. (July 23, 2010). Colombia and Obama's Latin American Policy: Time to Close Ranks and Support a Friend. Backgrounder, The Heritage Foundation.

Whitehead, L. and Nolte, D. (2012). The Obama Administration and Latin America: A Disappointing First Term? giga Focus, 6. 